This work is on a Creative Commons Attribution 4.0 International (CC DY 4.0) license, https:// creativecommons.org/licenses/by/4.0/. Access to this work was provided by the University of Maryland, Baltimore County (UMBC) ScholarWorks@UMBC digital repository on the Maryland Shared Open Access (MD-SOAR) platform.

Please provide feedback

Please support the ScholarWorks@UMBC repository by emailing scholarworks-group@umbc.edu and telling us what having access to this work means to you and why it's important to you. Thank you. 
Patient Educ Couns. 2014 August ; 96(2): 159-164. doi:10.1016/j.pec.2014.05.013.

\title{
An Unequal Burden: Poor Patient-Provider Communication and Sickle Cell Disease
}

\author{
Carlton Haywood Jr., PhD ${ }^{1}$, Shawn Bediako, $\mathrm{PhD}^{2}$, Sophie Lanzkron, $\mathrm{MD}^{3}$, Marie Diener- \\ West, $\mathrm{PhD}^{4}$, John Strouse, $\mathbf{M D}^{5}$, Jennifer Haythornthwaite, $\mathrm{PhD}^{6}$, Gladys Onojobi, MD${ }^{7}$, \\ Mary Catherine Beach, MD $^{8}$, and for the IMPORT Investigators \\ ${ }^{1}$ Department of Medicine, The Johns Hopkins School of Medicine, Baltimore, MD 21205, USA \\ 2Department of Psychology, The University of Maryland, Baltimore County, Baltimore MD 21250, \\ USA
}

${ }^{3}$ Department of Medicine, The Johns Hopkins School of Medicine, Baltimore, MD 21205, USA

${ }^{4}$ Department of Biostatistics, The Johns Hopkins Bloomberg School of Public Health, Baltimore MD 21205, USA

${ }^{5}$ Department of Medicine, The Johns Hopkins School of Medicine, Baltimore, MD 21205, USA

${ }^{6}$ Department of Psychiatry and Behavioral Sciences, The Johns Hopkins School of Medicine, Baltimore, MD 21287, USA

${ }^{7}$ Department of Medicine, The Howard University Hospital, Washington, DC 20060, USA

${ }^{8}$ Department of Medicine, The Johns Hopkins School of Medicine, Baltimore, MD 21205, USA

\section{Abstract}

Objective-To assess disparities in the quality of healthcare provider communication experienced by African-American adults with and without sickle cell disease (SCD) in the U.S.

Methods-Poor provider communication was assessed by the Provider Communication subscale of the Consumer Assessment of Healthcare Plans and Systems survey. The SCD sample was obtained from participants in a multicenter observational study of healthcare experiences. The national African-American sample data was obtained from published national estimates.

Results-The SCD sample was more likely than the national sample to report poor communication in 3 out of 4 communication domains: Listening (22.3\% vs. $11.5 \%$, p < 0.0001$)$; Showing Respect (26.1\% vs. 9.5\%, p < 0.0001); and Spending Enough Time (38.3\% vs. 16.2\%, p

(C) 2014 Elsevier Ireland Ltd. All rights reserved.

Corresponding Author at: Carlton Haywood Jr, PhD, MA, 1809 Ashland Avenue, Deering Hall, Room 210, Baltimore, MD 21205, 410-614-5571 (office), 410-614-5360 (fax), chaywoodjr@jhu.edu.

Publisher's Disclaimer: This is a PDF file of an unedited manuscript that has been accepted for publication. As a service to our customers we are providing this early version of the manuscript. The manuscript will undergo copyediting, typesetting, and review of the resulting proof before it is published in its final citable form. Please note that during the production process errors may be discovered which could affect the content, and all legal disclaimers that apply to the journal pertain.

Conflict of Interest Statement

The authors declare that there is no conflict of interest. 
$<0.0001$ ). Differences were consistent in young, but not old, patients and showed some variation by self-reported health status and education.

Conclusions-The communication difficulties experienced by persons with SCD do not appear reducible to their predominantly African-American race, but may result from more diseasespecific factors.

Practice Implications-Healthcare providers should take particular care in recognizing and demonstrating recommended communication skills with SCD patients as these patients may be particularly vulnerable to, and cognizant of, poor quality interactions.

\section{Keywords}

patient-provider communication; healthcare disparities; sickle cell disease

\section{Introduction}

Communication between patients and their healthcare providers is a fundamental aspect of healthcare quality that has a wide-ranging effect on the outcomes of care. Good communication is associated with greater satisfaction, adherence to medical advice, and symptom resolution. [1-3] Because of its critical role in the delivery of healthcare, the quality of patient-provider communication is routinely monitored as an indicator of the quality of the U.S. healthcare system. [4]

Despite its fundamental importance, it is well known that there exist troubling disparities in the quality of patient-provider communication. Patient factors associated with disparities in patient-provider communication quality include race and health status. African-American and Hispanic patients, for example, report poor communication with their providers more often than White patients.[5]

Sickle cell disease is a life-threatening genetic disorder of hemoglobin that causes severe acute and chronic pain, increased morbidity and early mortality and, given the predominantly African-American race of sickle cell disease (SCD) patients in the U.S, SCD patients may experience particularly poor communication with healthcare providers. Multiple studies indicate that SCD patients report deficiencies with the quality of the interpersonal care delivered to them. [6-9] Lattimer et al. found that hospitalized SCD patients were more likely than a national sample of hospitalized patients in the U.S. to report problems across multiple domains of interpersonal healthcare experiences. [10] Haywood et al. found that SCD patients seeking care in the emergency department (ED) had longer wait times to see a physician than a national sample of patients seeking care in the ED. [11] Treatment for pain is a primary reason behind the majority of healthcare encounters between persons with SCD and healthcare providers, yet poor communication is a barrier to the delivery of effective pain management. $[1,6,10,12,13]$

The extent to which the healthcare provider communication difficulties experienced by SCD patients is another facet of the problem of racial disparities in the quality of healthcare generally is not currently known. That is, are the problems in the interpersonal experience of care perceived by SCD patients an example of the larger issue of racial disparities in 
healthcare quality in the U.S., or are SCD patients subject to additional sources of disadvantage that place them at even greater risk of experiencing disparities in the quality of their care? This is an important question of social justice within the healthcare system as experienced by this traditionally underserved patient population. Further, disentangling the causes behind the poor quality of interpersonal care experienced by SCD patients is integral to developing interventions to improve the quality of the care delivered to this patient population, which is a health policy goal that has recently been prioritized by the Department of Health and Human Services.[14]

In this paper, we examine whether race predominately accounts for the high rates of poor communication between SCD patients and their healthcare providers. This study compared the prevalence of reports of poor communication between SCD patients and their providers to similar reports given by a national sample of African-American patients in the U.S. We hypothesized a priori that a greater proportion of SCD patients compared to the national sample would report poor communication with their healthcare providers.

\section{Methods}

\subsection{Study Design, Subjects and Setting}

This study was conducted as part of the Improving Patient Outcomes with Respect and Trust (IMPORT) study. The IMPORT study is a federally funded observational cohort study of SCD patient experiences with healthcare taking place at two academic medical centers in the mid-Atlantic region. This study was approved by the Institutional Review Boards at both the Johns Hopkins Medical Institutions, and Howard University.

Persons eligible to participate in the IMPORT study: 1) were age 15 years or older, 2) diagnosed with one of the following sickle hemoglobinopathies: HbSS, HbSC, Hb SS/Bthalassemia or $\mathrm{Hb} \mathrm{SS/a-thalassemia,} \mathrm{3)} \mathrm{reported} \mathrm{no} \mathrm{plans} \mathrm{to} \mathrm{move} \mathrm{in} \mathrm{the} \mathrm{next} \mathrm{three} \mathrm{years,}$ and 4) expressed willingness to adhere to study procedures. Research assistants recruited eligible patients from waiting rooms of adult and pediatric SCD clinics at the two study sites, and all study subjects provided written informed consent. To meet the objectives of the current analysis, we only used data from those IMPORT participants reporting their race as Black or African-American, and who reported their age as 18 years or older.

\subsection{Data Collection Procedures}

Participating patients completed a comprehensive baseline questionnaire administered by an audio computer-assisted self-interview (ACASI) system. The ACASI system read questions to the patient through a headset and allowed the patients to answer using touch-screen technology at a private computer station. On average, each ACASI interview took approximately 45 minutes to complete and patients were paid $\$ 50$ for their time. We collected data on their perceptions of the quality of prior healthcare experiences, basic demographic information, health status, clinical complications, and psychosocial attitudes. The specific measures collected and used in the current study are as follows:

\subsubsection{Dependent Variable: Quality of Previous Provider Communication-The} quality of the respondent's previous communication with healthcare providers was measured 
using the Provider Communication subscale of the Consumer Assessment of Healthcare Plans and Systems (CAHPS) survey instrument, available from the Agency for Healthcare Research and Quality (AHRQ). [15] With this measure, respondents assess the quality of their communication with providers over the previous 12-month period. Specifically, respondents were asked: In the last 12 months, how often did doctors or other health providers: 1 )...listen carefully to you?; 2)...explain things in a way you could understand?; 3)... show respect for what you had to say?; and 4)...spend enough time with you? Response options were "never", "sometimes", "usually", and "always". The response options were dichotomized, with responses of either "never" or "sometimes" denoting "poor provider communication".

2.2.2 Potential Confounders-We examined three patient characteristics as potential confounders: age (18 to 44, 45 to 64 , and 65+), education (less than high school, high school or GED, at least some college), and perceived health status (poor/fair, good/very good/ excellent).

\subsection{Analytic Methods}

We compared the proportion of SCD patients reporting poor communication with their healthcare providers over the prior 12-month period to data from a national sample of adult African-American patients in the U.S. from the National Healthcare Quality \& Disparities Reports Data Access Tool (NHQRDRnet) available on the AHRQ website. [16] To remove any effects of potentially confounding patient characteristics, we conducted stratified analyses whereby we calculated the proportion of SCD study respondents reporting poor communication stratified by age or perceived health status. We then compared differences in the stratified proportion from the SCD study to the corresponding stratified proportion found in the NHQRDRnet system using the binomial test. Exact 95\% CIs for the SCD group were calculated and reported for the sample overall and within each strata of the potential confounders.

To correct for the problem of multiple comparisons given the large number of hypotheses tested in this study (32 in all), we applied a Bonferroni correction to the statistical significance level used for the study, resulting in a study p-value $<0.0016(0.05 / 32)$. All analyses were conducted using Stata 12.1 statistical software.[17]

\section{Results}

\subsection{IMPORT Patient Characteristics}

Table 1 describes the demographic characteristics of the IMPORT study sample eligible for the current analysis. Two-hundred sixty four African-American adults with SCD in total were included in this analysis. Slightly over half (54.2\%) were female, approximately $48 \%$ perceived their health status as being "poor" or "fair", $51 \%$ had a high school degree or its equivalent, and $75 \%$ were between the ages of 18 and 44 . Because only 2 individuals in the SCD sample comprised the 65+ group, this older group was removed from all subsequent analyses involving age. 


\subsection{Overall Reports of Poor Provider Communication}

The results of the overall (non-stratified) comparisons of the proportions of patients reporting poor communication with healthcare providers comparing the IMPORT respondents to the national sample are found in table 2. For three of the four items, a greater proportion of the SCD sample reported poor communication with healthcare providers than did the national sample of African-American patients. The SCD patients were about twice as likely as the national African-American sample to report poor communication in the domain of providers listening carefully to the patient ( $22.3 \%$ vs. $11.5 \%$ ), about 3 times more likely to report poor communication in the domain of providers showing respect for what the patient had to say (26.1\% vs. 9.5\%), and a little over twice as likely to report that providers did not spend enough time with the patient (38.3\% vs. $16 \%$ ). A greater proportion of the SCD sample also reported poor provider communication in the domain of having things explained in a way they could understand, though this result did not reach the level of statistical significance established for this study.

\subsection{Reports of Poor Provider Communication Stratified by Age, Health Status, and Education}

Table 3 presents the reports of poor communication stratified separately by age and perceived health status. These analyses indicate that younger (age 18 to 44 ) patients showed differences in provider communication patterns that were not apparent in older (45 to 64) patients. Among the younger patient group a greater proportion of SCD patients reported poor provider communication in three (Listening; Showing Respect; and Spending Enough Time) of the four communication domains when compared to the national sample. Among those in the older age group, there were no statistically significant differences in any of the four communication domains.

Differences between the national sample and our SCD sample on Explaining were no longer significant when these groups were stratified according to self-reported good health (including good, very good or excellent health) or fair/poor health status (see Table 3). However, significant differences between the SCD and national sample patients remained on two communication domains (Showing Respect, Spending Enough Time) for both the fair/ poor health status and the good health status groups. Among those with worse perceived health, a greater proportion of the SCD sample reported poor provider communication in the domain of Listening.

Stratification by educational level suggested more differences between SCD patients and the national African-American sample in reports of poor provider communication among those with greater levels of educational attainment (table 4). Among respondents with a high school degree or GED, a greater proportion of SCD patients reported poor provider communication in three of the four communication domains under study. Only the domain of "having things explained in a way they could understand" lacked statistical significance among this group of patients. Among those with at least some college education, a greater proportion of SCD patients reported poor provider communication in two of the four domains (providers showing respect for what the patient had to say, and providers spending enough time with the patient). Among those with the lowest level of education (less than a 
high school degree or GED), none of the differences between the SCD sample and the national sample reached the level of statistical significance established for this study.

\section{Discussion and Conclusion}

\subsection{Discussion}

Our study found that SCD patients in the United States are at particular disadvantage regarding communication with healthcare providers when compared to a national sample of African-Americans. The SCD patients are far less likely to feel listened to, respected, and to have felt they had enough time spent with their provider. In numerous qualitative studies, SCD patients have reported negative experiences in talking to healthcare providers, $[6,7,18,19]$ although it has never been clear how these experiences compared to national norms or what might account for them. Because our study was able to account for patient race and adjust for health status, age, and education while making national comparisons, we believe that these poor communication experiences are not due to race or these other factors alone.

The magnitude of these differences are consistently greater than the magnitude of differences found in comparisons between African-American patients and White patients as reported by AHRQ on the same measures of communication. [16] This suggests that the SCD patients experience additional "layers of disadvantage" compared to other patient populations. That is, African-American patients tend to experience disparities in the quality of provider communication compared to White patients, and SCD patients experience even more difficulties in the quality of provider communication than typical African-American patients. Thus, SCD patients appear to be subject to a level of problematic interpersonal treatment when seeking healthcare that is even greater than populations already known to be vulnerable to mistreatment. This raises important concerns about social justice, or lack thereof, in the healthcare system for SCD patients, who appear to be a group that is particularly disadvantaged.

These findings suggest that the disadvantage experienced by SCD patients cannot be solely attributed to race, age, perceived health status, or education. What other factors, then, might contribute to SCD disadvantage? Additional patient factors may include the nature and complexity of SCD and the common complaint of pain that lacks objective findings. [20,21] Cognitive dysfunction among SCD patients may play a role here as SCD patients are known to be at increased risk for cognitive dysfunction, and patients with cognitive dysfunction have been found to provide worse ratings of the quality of their communication with providers when compared to patients without cognitive impairment. [22,23] Assessments of cognitive dysfunction among SCD patients should be incorporated into future research both as a primary predictor of perceived communication quality, or as an important confounding variable to be accounted for in multi-predictor studies of communication quality. Attitudes about the use of opioids in the treatment of chronic non-malignant pain, beliefs about the burden of substance addiction among the SCD patient population, [24-26] and lack of sufficient knowledge in treating the disease[6] are provider-level factors that may also contribute to SCD disadvantage. Research that assesses SCD patient ratings of provider behaviors (examining both verbal and nonverbal provider behaviors), as well as research 
that utilizes the ratings of independent observers of provider behavior, are necessary in order to identify those specific behaviors that have the largest effect on the perceived quality of the communication that occurred during the healthcare encounter. Finally, the very structure of the healthcare system and misconceptions about the true burden of pain caused by the disease[27] may also contribute. All of these factors are worthy of further study and testing, particularly if effective interventions are going to improve the quality of care delivered to this population.

What this suggests, though, is that SCD patients are subject to a constellation of factors that combine and interact in ways that place them at heightened risk for experiencing poor healthcare quality relative to that experienced by at least some sub-populations already identified and prioritized in efforts to reduce disparities in healthcare. Our findings indicate that SCD patients be added to the list of "disparity populations" in need of prioritization in health policy efforts.

Some limitations of our work must be considered. We were able to adjust for the effects of several patient characteristics that could potentially confound differences in poor communication between SCD patients and other patient populations (e.g., race, age, perceived health status, and education). Nevertheless, other potential confounders or explanatory variables could not be accounted for in this study. For example, it is possible and even likely - that there were varying levels of healthcare utilization between SCD patients and the national sample of African-American patients. While controlling for perceived health status may have provided some level of control for this factor, it is unlikely that this single variable could serve as a full proxy for healthcare utilization. Since the instructions for completing the provider communication items did not specify a particular reference provider, it is possible that the two patient groups considered experiences with different types of healthcare providers when responding to the provider communication items. Therefore, the common experience of SCD patients with acute sources of care (e.g., ED or inpatient hospital care) may provide a very different reference from the national sample who may have been more likely to reference ambulatory healthcare providers. If this is the case and these two types of settings differ in the observed types of communications, this would contribute to the higher levels of poor communication reported by the SCD patient sample. Nevertheless, individuals in both samples were asked the same, non-specific set of items, so it is also possible that both groups considered the totality of their healthcare experiences when responding to the questions. Future work would strengthen our understanding of this potential confound by comparing communication experiences of African-American patients from different disease groups (e.g., SCD vs. asthma) receiving care in the same or similar healthcare settings. Finally, the SCD patients represent a regional sample, which may raise some concerns about the generalizability of our results. However, we conducted a sensitivity analysis by comparing our regional sample to state-specific results provided by AHRQ and the findings did not differ from our main analysis.

\subsection{Conclusions}

Our work highlights an urgent problem regarding disparities in healthcare quality experienced by individuals with SCD. Our findings suggest that efforts to improve the 
quality of healthcare delivered to patients with SCD must go beyond those strategies that solely seek to reduce or eliminate disparities between minority patients and other patient populations generally. Our work suggests that the problems in the quality of care experienced by patients with SCD cannot be reduced to an effect of race. A multifactorial approach is needed such that all of the potential causal contributors to the poor quality of SCD care are taken into account. We have previously shown that a video-based educational intervention reduces the negative attitudes that many healthcare providers have about patients with SCD. [28] This and other types of interventions need to be developed and translated into healthcare systems to systematically address all of the potential causes of the poor quality of care delivered to SCD patients. One example of a needed intervention involves providing education and training to patients that allows them to ask more questions and be more engaged in the healthcare encounter, while at the same time providing education to physicians that facilitates their encouragement of patient involvement and question asking during encounters, an approach that has been shown in prior studies to lead to improvements in the patient perceptions of the quality of communication during encounters. [29] Additionally, research in this area would be strengthened with studies that used both objective and patient-reported measures of the quality of provider communication. As a number of factors in addition to provider behaviors might affect patient perceptions of the quality of their communication with providers, it would be helpful to determine just how well patient-reported measures of quality correspond with objectives reports as provided by independent observers. Only through comprehensive, systematic, and sustained approaches might we eventually realize our federal and moral mandates to improve the quality of care delivered to persons with $\mathrm{SCD}$, a population that for far too long has been lacking the same high quality of interpersonal care that all patient populations deserve to experience.

\subsection{Practice Implications}

Multiple practice implications follow from our results. Our finding that poor communication perceived by SCD patients was not reducible to their predominately African-American race suggests that interventions and practices designed to reduce racial and ethnic disparities in communication among different patient populations may not completely eliminate the problem as it affects and is perceived by persons with SCD. More specifically tailored practices may need to be implemented in order to mitigate barriers to high quality communication that are specific to, or increasingly present among, patients with SCD. Further, healthcare providers treating SCD patients may need to take particular care to recognize and demonstrate those communication skills recommended for all patients as SCD patients may be particularly cognizant of, and on the lookout for, signs of poor communication from their providers. From a policy perspective, our research promotes the need for systems approaches that encourage or facilitate better physician communication with patients, such as reducing the pressures of time that face physicians which may lead to shorter visits with patients, or through reimbursement mechanisms that facilitate more patient-centered approaches to care. Our research also encourages systematic changes to the way in which care is delivered to SCD patients by supporting the growth of so-called "sickle cell day hospitals" or "comprehensive care centers" which seek to provide a comprehensive continuity of care to SCD patients from providers specially trained, and with a special 
interest in, SCD as these approaches have been shown to improve communication outcomes for this population. [30,31]

\section{Acknowledgments}

The authors confirm that all patient/personal identifiers have been removed or disguised so the patient/person(s) described are not identifiable and cannot be identified through the details of the story.

The authors thank all members and participants of the IMPORT study for their contributions. The full list of IMPORT investigators includes the authors, as well as the following individuals - Johns Hopkins Investigators: C. Patrick Carroll, MD; Tanita Woodson, Jordan Wilks, Benjamin Ajiboye, Nina Shah. Howard University Investigators: Abiodun Akintilo; Margaret Fadojutimi-Akinsiku; Patricia Oneal, MD; Adriana Medina; Nouraie, Seyed- Mehdi; John Kwagyan; Kemi Owoyemi; and Ronke Ajala.

Study data were collected and managed using REDCap electronic data capture tools hosted at Johns Hopkins University. REDCap (Research Electronic Data Capture) is a secure, web-based application designed to support data capture for research studies, providing: 1) an intuitive interface for validated data entry; 2) audit trails for tracking data manipulation and export procedures; 3 ) automated export procedures for seamless data downloads to common statistical packages; and 4) procedures for importing data from external sources.

Funding

This study was funded by a grant from the National, Heart, Lung and Blood Institute (NHLBI) (\#1R01HL088511-01). Dr. Haywood's effort was funded by a Career Development Award from the NHLBI (\#1K01HL108832-01). Dr. Lanzkron's effort was funded by a Career Development Award from the NHLBI (\#K23HL083089). The funders played no role in the design and conduct of the study; collection, management, analysis, and interpretation of the data; or preparation, review, or approval of the manuscript. The content is solely the responsibility of the authors and does not necessarily represent the official views of the National Institutes of Health.

\section{References}

1. Haywood C Jr. Lanzkron S, Ratanawongsa N, Bediako SM, Lattimer L, Powe NR, Beach MC. The association of provider communication with trust among adults with sickle cell disease. J.Gen.Intern.Med. 2010; 25:543-548. [PubMed: 20195785]

2. Stewart MA. Effective physician-patient communication and health outcomes: a review. CMAJ. 1995; 152:1423-1433. [PubMed: 7728691]

3. Street RL Jr. Makoul G, Arora NK, Epstein RM. How does communication heal? Pathways linking clinician-patient communication to health outcomes. Patient Educ.Couns. 2009; 74:295-301. [PubMed: 19150199]

4. 2011 National Healthcare Quality Report. 2012

5. 2011 National Healthcare Disparities Report. 2012

6. Haywood C Jr. Beach MC, Lanzkron S, Strouse JJ, Wilson R, Park H, Witkop C, Bass EB, Segal JB. A systematic review of barriers and interventions to improve appropriate use of therapies for sickle cell disease. J.Natl.Med.Assoc. 2009; 101:1022-1033. [PubMed: 19860302]

7. Maxwell K, Streetly A, Bevan D. Experiences of hospital care and treatment seeking for pain from sickle cell disease: qualitative study. BMJ. 1999; 318:1585-1590. [PubMed: 10364116]

8. Elander J, Midence K. A review of evidence about factors affecting quality of pain management in sickle cell disease. Clin.J.Pain. 1996; 12:180-193. [PubMed: 8866159]

9. Wright K, Adeosum O. Barriers to effective pain management in sickle cell disease. Br.J.Nurs. 2009; 18:158-161. [PubMed: 19223799]

10. Lattimer L, Haywood C Jr. Lanzkron S, Ratanawongsa N, Bediako SM, Beach MC. Problematic hospital experiences among adult patients with sickle cell disease. J.Health Care Poor Underserved. 2010; 21:1114-1123. [PubMed: 21099065]

11. Haywood C Jr. Tanabe P, Naik R, Beach MC, Lanzkron S. The impact of race and disease on sickle cell patient wait times in the emergency department. Am.J.Emerg.Med. 2013 
12. Haywood C Jr. Lanzkron S, Ratanawongsa N, Bediako SM, Lattimer-Nelson L, Beach MC. Hospital self-discharge among adults with sickle-cell disease (SCD): associations with trust and interpersonal experiences with care. J.Hosp.Med. 2010; 5:289-294. [PubMed: 20533577]

13. Ratanawongsa N, Haywood C Jr. Bediako SM, Lattimer L, Lanzkron S, Hill PM, Powe NR, Beach MC. Health care provider attitudes toward patients with acute vaso-occlusive crisis due to sickle cell disease: development of a scale. Patient Educ.Couns. 2009; 76:272-278. [PubMed: 19233587]

14. Office of Minority Health. Sickle Cell Disease: Increasing Access and Improving Care. 2011

15. Hays RD, Shaul JA, Williams VS, Lubalin JS, Harris-Kojetin LD, Sweeny SF, Cleary PD. Psychometric properties of the CAHPS 1.0 survey measures. Consumer Assessment of Health Plans Study. Med.Care. 1999; 37:MS22-MS31. [PubMed: 10098556]

16. National Healthcare Quality \& Disparities Reports (NHQRDR) Data Access Tool.

17. StataCorp. Stata Statistical Software: Release 12. 2011

18. Elander J, Beach MC, Haywood C. Respect, trust, and the management of sickle cell disease pain in hospital: comparative analysis of concern-raising behaviors, preliminary model, and agenda for international collaborative research to inform practice. Ethn.Health. 2011; 16:405-421. [PubMed: 21797726]

19. Alleyne J, Thomas VJ. The management of sickle cell crisis pain as experienced by patients and their carers. J.Adv.Nurs. 1994; 19:725-732. [PubMed: 8021394]

20. Labbe E, Herbert D, Haynes J. Physicians' attitude and practices in sickle cell disease pain management. J.Palliat.Care. 2005; 21:246-251. [PubMed: 16483093]

21. Pack-Mabien A, Labbe E, Herbert D, Haynes J Jr. Nurses' attitudes and practices in sickle cell pain management. Appl.Nurs.Res. 2001; 14:187-192. [PubMed: 11699021]

22. Vichinsky EP, Neumayr LD, Gold JI, Weiner MW, Rule RR, Truran D, Kasten J, Eggleston B, Kesler K, McMahon L, Orringer EP, Harrington T, Kalinyak K, De Castro LM, Kutlar A, Rutherford CJ, Johnson C, Bessman JD, Jordan LB, Armstrong FD. Neuropsychological Dysfunction and Neuroimaging Adult Sickle Cell Anemia Study Group. Neuropsychological dysfunction and neuroimaging abnormalities in neurologically intact adults with sickle cell anemia. JAMA. 2010; 303:1823-1831. [PubMed: 20460621]

23. Kripalani S, Jacobson TA, Mugalla IC, Cawthon CR, Niesner KJ, Vaccarino V. Health literacy and the quality of physician-patient communication during hospitalization. J.Hosp.Med. 2010; 5:269275. [PubMed: 20533572]

24. Waldrop RD, Mandry C. Health professional perceptions of opioid dependence among patients with pain. Am.J.Emerg.Med. 1995; 13:529-531. [PubMed: 7662056]

25. Shapiro BS, Benjamin LJ, Payne R, Heidrich G. Sickle cell-related pain: perceptions of medical practitioners. J.Pain Symptom Manage. 1997; 14:168-174. [PubMed: 9291703]

26. Solomon LR. Treatment and prevention of pain due to vaso-occlusive crises in adults with sickle cell disease: an educational void. Blood. 2008; 111:997-1003. [PubMed: 17940207]

27. Smith WR, Penberthy LT, Bovbjerg VE, McClish DK, Roberts JD, Dahman B, Aisiku IP, Levenson JL, Roseff SD. Daily assessment of pain in adults with sickle cell disease. Ann.Intern.Med. 2008; 148:94-101. [PubMed: 18195334]

28. Haywood C Jr. Lanzkron S, Hughes MT, Brown R, Massa M, Ratanawongsa N, Beach MC. A video-intervention to improve clinician attitudes toward patients with sickle cell disease: the results of a randomized experiment. J.Gen.Intern.Med. 2011; 26:518-523. [PubMed: 21181560]

29. Thompson SC, Nanni C, Schwankovsky L. Patient-oriented interventions to improve communication in a medical office visit. Health Psychol. 1990; 9:390-404. [PubMed: 2373065]

30. Benjamin LJ, Swinson GI, Nagel RL. Sickle cell anemia day hospital: an approach for the management of uncomplicated painful crises. Blood. 2000; 95:1130-1136. [PubMed: 10666181]

31. Aisiku IP, Penberthy LT, Smith WR, Bovbjerg VE, McClish DK, Levenson JL, Roberts JD, Roseff SD. Patient satisfaction in specialized versus nonspecialized adult sickle cell care centers: the PiSCES study. J.Natl.Med.Assoc. 2007; 99:886-890. [PubMed: 17722665] 


\section{Highlights}

Sickle cell patients report poor quality communication with healthcare providers

The role of African-American race in explaining those problems is unknown

We compare sickle cell and African-American patient reports of poor, communication

African-American race did not completely account for sickle cell patient reports

Sickle cell patients appear particularly vulnerable to poor provider communication 
Table 1

Characteristics of the IMPORT Study Sickle Cell Disease Sample $(\mathrm{N}=264)$

\begin{tabular}{|l|l|l|}
\hline & No. & $\%$ \\
\hline Patient Sex & & \\
\hline Male & 121 & $45.8 \%$ \\
\hline Female & 143 & $54.2 \%$ \\
\hline Total & 264 & $100.0 \%$ \\
\hline Self-Reported Age & & \\
\hline $18-44$ & 198 & $75.0 \%$ \\
\hline 45-64 & 64 & $24.2 \%$ \\
\hline $\begin{array}{l}\text { 65+ } \\
\text { Total }\end{array}$ & 2 & $0.8 \%$ \\
\hline $\begin{array}{l}\text { Perceived Health Status } \\
\text { In general, would you say your } \\
\text { health is:) }\end{array}$ & 264 & $100.0 \%$ \\
\hline Good/V.Good/Excellent & 136 & $51.7 \%$ \\
\hline Poor/Fair & 127 & $48.3 \%$ \\
\hline Total ${ }^{\dagger}$ & 263 & $100.0 \%$ \\
\hline $\begin{array}{l}\text { Education } \\
\text { What is the highest degree or } \\
\text { diploma you have?) }\end{array}$ & 31 & $12.0 \%$ \\
\hline Less than HS & 132 & $51.0 \%$ \\
\hline HS Grad or GED & 96 & $37.1 \%$ \\
\hline At least some college & 259 & $100.0 \%$ \\
\hline Total ${ }^{\dagger}$ & & \\
\hline
\end{tabular}

${ }^{\dagger}$ Total does not add to 264 due to missing values 
Table 2

Prevalence of Poor Communication in Health Care: National African-American Sample vs. IMPORT Study Sickle Cell Disease Sample ( $\mathrm{n}=264)$

\begin{tabular}{|c|c|}
\hline $\begin{array}{l}\text { In the last } 12 \text { months, how often did } \\
\text { doctors or other health providers... }\end{array}$ & $\begin{array}{l}\text { \% Reporting Poor Communication } \\
\text { (response of "sometimes" or "never") }\end{array}$ \\
\hline \multicolumn{2}{|l|}{ listen carefully to you? } \\
\hline National African American Sample ${ }^{\dagger}$ & 11.5 \\
\hline $\begin{array}{l}\text { SCD Sample } \\
(95 \% \text { CI })\end{array}$ & $\begin{array}{c}22.3 \\
{[17.5,27.9]}\end{array}$ \\
\hline P-value & $0.000001^{*}$ \\
\hline \multicolumn{2}{|l|}{$\begin{array}{l}\text {...explain things in a way you could } \\
\text { understand? }\end{array}$} \\
\hline National African American Sample & 11.6 \\
\hline $\begin{array}{l}\text { SCD Sample } \\
(95 \% \text { CI })\end{array}$ & $\begin{array}{c}18.2 \\
{[13.7,23.4]}\end{array}$ \\
\hline P-value & 0.0019 \\
\hline \multicolumn{2}{|l|}{$\begin{array}{l}\text {...show respect for what you had to } \\
\text { say? }\end{array}$} \\
\hline National African American Sample & 9.5 \\
\hline $\begin{array}{l}\text { SCD Sample } \\
(95 \% \mathrm{CI})\end{array}$ & $\begin{array}{c}26.1 \\
{[20.9,31.9]}\end{array}$ \\
\hline P-value & $<0.000001^{*}$ \\
\hline \multicolumn{2}{|l|}{...spend enough time with you? } \\
\hline National African American Sample & 16.2 \\
\hline $\begin{array}{l}\text { SCD Sample } \\
(95 \% \text { CI })\end{array}$ & $\begin{array}{c}38.3 \\
{[32.4,44.4]}\end{array}$ \\
\hline P-value & $<0.000001^{*}$ \\
\hline
\end{tabular}


Table 3

Prevalence of Poor Communication in Health Care: National African-American Sample vs. IMPORT Study Sickle Cell Disease Sample Stratified by Age and Perceived Health Status

\begin{tabular}{|c|c|c|c|c|}
\hline \multirow{3}{*}{$\begin{array}{l}\text { In the last } 12 \\
\text { months, how often } \\
\text { did doctors or } \\
\text { other health } \\
\text { providers... }\end{array}$} & \multicolumn{4}{|c|}{$\begin{array}{l}\text { \% Reporting Poor Communication } \\
\text { (response of "sometimes" or "never" }\end{array}$} \\
\hline & \multicolumn{2}{|c|}{ Age (years) } & \multicolumn{2}{|c|}{ Perceived Health Status } \\
\hline & $\begin{array}{c}18-44 \\
(\operatorname{SCD} n=198)\end{array}$ & $\begin{array}{c}45-64 \\
(\operatorname{SCD} n=64)\end{array}$ & $\begin{array}{c}\text { Good/V.Good/Excellent } \\
(\text { SCD n = 136) }\end{array}$ & $\begin{array}{c}\text { Poor/Fair } \\
(\mathbf{S C D} \mathbf{n}=127) \\
\end{array}$ \\
\hline \multicolumn{5}{|l|}{$\begin{array}{l}\text {...listen carefully } \\
\text { to you? }\end{array}$} \\
\hline $\begin{array}{l}\text { National African } \\
\text { American } \\
\text { Sample }^{\dagger}\end{array}$ & 12.7 & 10.6 & 10.5 & 15.8 \\
\hline $\begin{array}{l}\text { SCD Sample } \\
(95 \% \text { CI })\end{array}$ & $\begin{array}{c}21.7 \\
{[16.2,28.1]}\end{array}$ & $\begin{array}{c}23.4 \\
{[13.8,35.7]}\end{array}$ & $\begin{array}{c}15.4 \\
{[9.8,22.6]}\end{array}$ & $\begin{array}{c}29.1 \\
{[21.4,37.9]}\end{array}$ \\
\hline P-value & $0.00038^{*}$ & 0.0032 & 0.068 & $0.00014^{*}$ \\
\hline \multicolumn{5}{|l|}{$\begin{array}{l}\text {...explain things } \\
\text { in a way you } \\
\text { could } \\
\text { understand? }\end{array}$} \\
\hline $\begin{array}{l}\text { National African } \\
\text { American Sample }\end{array}$ & 12.8 & 10.0 & 9.9 & 19.2 \\
\hline $\begin{array}{l}\text { SCD Sample } \\
(95 \% \mathrm{CI})\end{array}$ & $\begin{array}{c}20.2 \\
{[14.8,26.5]} \\
\end{array}$ & $\begin{array}{c}12.5 \\
{[5.5,23.2]} \\
\end{array}$ & $\begin{array}{c}16.2 \\
{[10.4,23.5]} \\
\end{array}$ & $\begin{array}{c}20.5 \\
{[13.8,28.5]} \\
\end{array}$ \\
\hline P-value & 0.0038 & 0.528 & 0.021 & 0.735 \\
\hline \multicolumn{5}{|l|}{$\begin{array}{l}\text {...show respect } \\
\text { for what you had } \\
\text { to say? }\end{array}$} \\
\hline $\begin{array}{l}\text { National African } \\
\text { American Sample }\end{array}$ & 10.1 & 9.8 & 7.9 & 16.9 \\
\hline $\begin{array}{l}\text { SCD Sample } \\
(95 \% \text { CI })\end{array}$ & $\begin{array}{c}28.8 \\
{[22.6,35.6]}\end{array}$ & $\begin{array}{c}17.2 \\
{[8.9,28.7]}\end{array}$ & $\begin{array}{c}22.8 \\
{[16.0,30.8]}\end{array}$ & $\begin{array}{c}29.1 \\
{[21.4,37.9]}\end{array}$ \\
\hline P-value & $<0.000001^{*}$ & 0.056 & $<0.000001^{*}$ & $0.00054^{*}$ \\
\hline \multicolumn{5}{|l|}{$\begin{array}{l}\text {...spend enough } \\
\text { time with you? }\end{array}$} \\
\hline $\begin{array}{l}\text { National African } \\
\text { American Sample }\end{array}$ & 18.8 & 14.8 & 14.9 & 21.9 \\
\hline $\begin{array}{l}\text { SCD Sample } \\
(95 \% \text { CI })\end{array}$ & $\begin{array}{c}43.9 \\
{[36.9,51.2]}\end{array}$ & $\begin{array}{c}21.9 \\
{[12.5,33.9]}\end{array}$ & $\begin{array}{c}29.4 \\
{[21.9,37.8]}\end{array}$ & $\begin{array}{c}48.0 \\
{[39.1,57.1]}\end{array}$ \\
\hline P-value & $<0.000001^{*}$ & 0.114 & $0.000017^{*}$ & $<0.000001^{*}$ \\
\hline
\end{tabular}

Denotes statistically significant difference in proportions at $\mathrm{p}<0.0016$ (Bonferroni adjusted significance)

${ }^{\dagger}$ National African-American sample proportion considered as the "expected" proportion 
Table 4

Prevalence of Poor Communication in Health Care: National African-American Sample vs. IMPORT Study SCD Sample Stratified by Education

\begin{tabular}{|c|c|c|c|}
\hline \multirow{3}{*}{$\begin{array}{l}\text { In the last } 12 \text { months, } \\
\text { how often did doctors } \\
\text { or other health } \\
\text { providers... }\end{array}$} & \multicolumn{3}{|c|}{$\begin{array}{l}\text { \% Reporting Poor Communication } \\
\text { (response of "sometimes" or "never") }\end{array}$} \\
\hline & \multicolumn{3}{|c|}{ Education } \\
\hline & $\begin{array}{c}\text { Less than HS } \\
(\text { SCD Sample } n=31)\end{array}$ & $\begin{array}{c}\text { HS Grad or GED } \\
(\text { SCD Sample } n=132)\end{array}$ & $\begin{array}{l}\text { At least some college } \\
\text { (SCD Sample } n=96 \text { ) }\end{array}$ \\
\hline \multicolumn{4}{|l|}{$\begin{array}{l}\text {...listen carefully to } \\
\text { you? }\end{array}$} \\
\hline $\begin{array}{l}\text { National African- } \\
\text { American Sample }\end{array}$ & $13.8 \%$ & $12.5 \%$ & $9.7 \%$ \\
\hline $\begin{array}{l}\text { SCD Sample } \\
(95 \% \text { CI })\end{array}$ & $\begin{array}{c}29.0 \% \\
{[14.2 \%, 48.0 \%]}\end{array}$ & $\begin{array}{c}23.5 \% \\
{[16.5 \%, 31.6 \%]}\end{array}$ & $\begin{array}{c}18.8 \% \\
{[11.5 \%, 28.0 \%]}\end{array}$ \\
\hline P-value & 0.031 & $0.0005^{*}$ & 0.0054 \\
\hline \multicolumn{4}{|l|}{$\begin{array}{l}\text {...explain things in a } \\
\text { way you could } \\
\text { understand? }\end{array}$} \\
\hline $\begin{array}{l}\text { National African- } \\
\text { American Sample }\end{array}$ & $16.5 \%$ & $13.1 \%$ & $8.4 \%$ \\
\hline $\begin{array}{l}\text { SCD Sample } \\
(95 \% \text { CI })\end{array}$ & $\begin{array}{c}19.4 \% \\
{[7.5 \%, 37.5 \%]}\end{array}$ & $\begin{array}{c}19.7 \% \\
{[13.3 \%, 27.5 \%]}\end{array}$ & $\begin{array}{c}15.6 \% \\
{[9.0 \%, 24.5 \%]}\end{array}$ \\
\hline P-value & 0.629 & 0.038 & 0.016 \\
\hline \multicolumn{4}{|l|}{$\begin{array}{l}\text {...show respect for } \\
\text { what you had to say? }\end{array}$} \\
\hline $\begin{array}{l}\text { National African- } \\
\text { American Sample }\end{array}$ & $12.5 \%$ & $11.5 \%$ & $6.8 \%$ \\
\hline $\begin{array}{l}\text { SCD Sample } \\
(95 \% \text { CI })\end{array}$ & $\begin{array}{c}29.0 \% \\
{[14.2 \%, 48.0 \%]}\end{array}$ & $\begin{array}{c}29.5 \% \\
{[21.9 \%, 38.1 \%]}\end{array}$ & $\begin{array}{c}19.8 \% \\
{[12.4 \%, 29.2 \%]}\end{array}$ \\
\hline P-value & 0.011 & $<0.000001^{*}$ & $0.000022^{*}$ \\
\hline \multicolumn{4}{|l|}{$\begin{array}{l}\text {...spend enough time } \\
\text { with you? }\end{array}$} \\
\hline $\begin{array}{l}\text { National African- } \\
\text { American Sample }\end{array}$ & $18.7 \%$ & $16.3 \%$ & $14.9 \%$ \\
\hline $\begin{array}{l}\text { SCD Sample } \\
(95 \% \mathrm{CI})\end{array}$ & $\begin{array}{c}32.3 \% \\
{[16.7 \%, 51.4 \%]}\end{array}$ & $\begin{array}{c}39.4 \% \\
{[31.0 \%, 48.3 \%]}\end{array}$ & $\begin{array}{c}39.6 \% \\
{[29.7 \%, 50.0 \%]}\end{array}$ \\
\hline P-value & 0.064 & $<0.000001^{*}$ & $<0.000001^{*}$ \\
\hline
\end{tabular}

Denotes statistically significant difference in proportions at $\mathrm{p}<0.0016$ (Bonferroni adjusted significance)

† National African-American sample proportion considered as the "expected" proportion 